\title{
Edyta Żmurkow-Poteralska*
}

\section{INNOWACYJNOŚĆ A ZMIANY NA RYNKU PRACY W POLSCE}

\begin{abstract}
Streszczenie. Innowacyjność stanowi współcześnie jeden z najistotniejszych czynników zmian zachodzących w gospodarce. Zmiany te uwidaczniają się we wszystkich jej obszarach, w tym w obrębie rynku pracy, gdzie dochodzi do dostosowywania zasobu pracujących do potrzeb nowoczesnej gospodarki. Celem artykułu jest próba uchwycenia zależności pomiędzy innowacyjnością gospodarki a zmianami obserwowanymi na rynku pracy w Polsce. W ramach badania dokonano pomiaru i analizy poziomu innowacyjności w oparciu o miernik syntetyczny. W następnym kroku analizie poddano zmiany struktury pracujących w przekroju sektorów i sekcji gospodarki zgodnie z Polską Klasyfikacją Działalności z 2007 roku oraz sektorów wyróżnionych ze względu na poziom zaawansowania techniki i wiedzy, a także w przekroju kwalifikacyjnozawodowym. Ostatni element analizy stanowi próba identyfikacji związku pomiędzy poziomem innowacyjności a strukturą zatrudnienia.
\end{abstract}

Słowa kluczowe: innowacyjność, wskaźnik syntetyczny, rynek pracy, struktura zatrudnienia, związek.

\section{WPROWADZENIE}

Innowacyjność rozumiana jako skłonność i zdolność do tworzenia, absorbowania i wdrażania szeroko pojętych innowacji (Matusiak 2011: 119) stanowi istotny czynnik determinujący zmiany we współczesnej gospodarce. Innowacje pojawiające się w gospodarce, czy to w sferze produkcji, technologii, organizacji pracy czy zarządzania, wywołują procesy dostosowawcze we wszystkich jej obszarach, w tym w obszarze rynku pracy. Do podstawowych mechanizmów oddziaływania innowacji na zatrudnienie zalicza się efekt wypierania siły roboczej skutkujący redukcją zatrudnienia, szczególnie w sektorach tradycyjnych i nieefektywnych oraz wśród pracowników o niskich kwalifikacjach, a także efekt kompensacji prowadzący do powstawania nowych miejsc pracy, zwłaszcza w sektorach nowoczesnych technologii (Kwiatkowska 2007: 27-29). W konsekwencji dochodzi do zmian w strukturze zatrudnienia stanowiących efekt dostosowywania zasobu pracujących do potrzeb innowacyjnej gospodarki.

Celem artykułu jest próba uchwycenia zależności pomiędzy innowacyjnością gospodarki a zmianami obserwowanymi na rynku pracy w Polsce. Głównym

\footnotetext{
* Uniwersytet Łódzki. Wydział Ekonomiczno-Socjologiczny, Katedra Ekonometrii Przestrzennej, edyta.zmurkow@gmail.com
} 
przedmiotem zainteresowania jest kwestia rosnącego znaczenia innowacji w procesie przemian następujących w obszarze rynku pracy, a w szczególności ich oddziaływania na zmiany struktury zapotrzebowania gospodarki na pracowników. $\mathrm{W}$ ramach badania dokonano pomiaru i analizy poziomu innowacyjności w oparciu o wskaźnik syntetyczny. W dalszej kolejności analizie poddano zmiany struktury pracujących w przekroju rodzajów działalności oraz sektorów wyróżnionych ze względu na poziom zaawansowania techniki i zaangażowania wiedzy, a także w przekroju zawodowo-kwalifikacyjnym. Ostatnim elementem analizy jest próba identyfikacji związku pomiędzy poziomem innowacyjności i zmianami obserwowanymi w strukturze zatrudnienia. W opracowaniu zaprezentowano wyniki analiz przeprowadzonych dla lat 2008-2013 ${ }^{1}$ na poziomie województw w Polsce. Dane zaczerpnięto z Banku Danych Lokalnych Głównego Urzędu Statystycznego, baz danych Eurostatu oraz baz z Badania Aktywności Ekonomicznej Ludności (BAEL).

\section{POZIOM INNOWACYJNOŚCI WOJEWÓDZTW W POLSCE}

W celu pomiaru poziomu innowacyjności województw w Polsce zbudowano syntetyczny wskaźnik innowacyjności wzorowany na wskaźniku wyznaczanym dla regionalnej przestrzeni europejskiej w cyklicznym badaniu Regional Innovation Scoreboard (RIS) prowadzonym przez Komisję Europejską. Wskaźnik ten stanowi jednocześnie zmodyfikowaną i zaktualizowaną wersję wskaźnika innowacyjności prezentowanego we wcześniejszych opracowaniach (por.: Gajdos, Żmurkow 2012; Żmurkow-Poteralska 2012; Gajdos, Trzeźwińska, Żmurkow 2011).

Do budowy wskaźnika wytypowano 14 wskaźników cząstkowych, które poddano analizie zmienności i korelacji. Przeprowadzone analizy wykazały konieczność usunięcia ze zbioru zmiennych dwóch wskaźników silnie skorelowanych z większością pozostałych mierników. Ostatecznie syntetyczny wskaźnik innowacyjności został zbudowany z wykorzystaniem 12 mierników obrazujących trzy główne obszary innowacyjności: bodźce, aktywność firm oraz efekty (Tabela 1).

\footnotetext{
${ }^{1}$ Przy wyborze zakresu czasowego analizy kierowano się dostępnością danych oraz ich spójnością w całym okresie. Istnieje kilka powodów pominięcia w analizie lat sprzed 2008 roku: po pierwsze w okresie tym nie są dostępne dane dotyczące działalności innowacyjnej przedsiębiorstw w sektorze usług, a gromadzenie danych dotyczących działalności innowacyjnej przedsiębiorstw przemysłowych podlegało innej metodologii. Od roku 2008 (włącznie) badaniem pełnym objęte były przedsiębiorstwa przemysłowe liczące powyżej 49 pracujących, a badaniem na próbie reprezentacyjnej przedsiębiorstwa o liczbie pracujących od 10 do 49 osób; w latach wcześniejszych (2005 i 2007) badane były tylko przedsiębiorstwa przemysłowe liczące powyżej 49 osób (badanie pełne). Po drugie od 2008 roku dane w przekroju sektorowym gromadzone są w układzie Polskiej Klasyfikacji Działalności z 2007 roku (PKD 2007), co sprawia, że są one nieporównywalne z danymi z lat wcześniejszych (zgodnymi z PKD z 2004 roku).
} 
Tabela 1. Wskaźniki cząstkowe włączone do syntetycznego wskaźnika innowacyjności

\begin{tabular}{|c|c|}
\hline Obszar & Wskaźnik \\
\hline & Bodźce \\
\hline \multirow{3}{*}{ Zasoby ludzkie } & $\begin{array}{l}\text { Uczestnicy studiów doktoranckich na } 1 \text { tys. ludności w wieku 25-34 } \\
\text { lata }\end{array}$ \\
\hline & $\begin{array}{l}\text { Udział ludności w wieku 30-34 lata z wyższym wykształceniem* } \\
\text { (w \%) }\end{array}$ \\
\hline & $\begin{array}{l}\text { Udział ludności w wieku 20-24 lata z wykształceniem co najmniej } \\
\text { ponadgimnazjalnym (w \%) }\end{array}$ \\
\hline Finanse i wsparcie & Udział nakładów na B+R w PKB (w \%) \\
\hline \multicolumn{2}{|r|}{ Aktywność firm } \\
\hline \multirow{2}{*}{$\begin{array}{l}\text { Powiązania } \\
\text { i przedsiębiorczość }\end{array}$} & $\begin{array}{l}\text { Odsetek przedsiębiorstw z sektora przemysłowego współpracujących } \\
\text { w zakresie działalności innowacyjnej (w \%) }\end{array}$ \\
\hline & $\begin{array}{l}\text { Odsetek przedsiębiorstw z sektora usług współpracujących w zakresie } \\
\text { działalności innowacyjnej (w \%) }\end{array}$ \\
\hline \multirow[t]{2}{*}{ Kapitał intelektualny } & Liczba wynalazków krajowych** zgłoszonych na 1 mln ludności \\
\hline & $\begin{array}{ll}\text { Efekty } \\
\end{array}$ \\
\hline \multirow{2}{*}{ Innowatorzy } & $\begin{array}{l}\text { Udział innowacyjnych przedsiębiorstw w ogóle przedsiębiorstw } \\
\text { z sektora przemysłowego (w \%) }\end{array}$ \\
\hline & $\begin{array}{l}\text { Udział innowacyjnych przedsiębiorstw w ogóle przedsiębiorstw } \\
\text { z sektora usług (w \%) }\end{array}$ \\
\hline \multirow{3}{*}{ Efekty ekonomiczne } & $\begin{array}{l}\text { Udział pracujących w przemyśle wysokiej i średnio-wysokiej techniki } \\
\text { w ogólnej liczbie pracujących (w \%) }\end{array}$ \\
\hline & $\begin{array}{l}\text { Udział pracujących w usługach „opartych na wiedzy” (KIS - ang. } \\
\text { Knowledge Intensive Services) w ogólnej liczbie pracujących (w \%) }\end{array}$ \\
\hline & $\begin{array}{l}\text { Udział przychodów netto ze sprzedaży produktów innowacyjnych*** } \\
\text { w przedsiębiorstwach przemysłowych (w \%) }\end{array}$ \\
\hline
\end{tabular}

* Wykształcenie na poziomie ISCED 5-8 (wg ISCED 2011).

** Zgłoszenia do Urzędu Patentowego Rzeczypospolitej Polskiej.

*** Produkty innowacyjne dla firmy i/lub dla rynku.

Źródło: opracowanie własne na podstawie (Regional Innovation... 2014: 6, 8-9).

Zgodnie z metodologią RIS, wskaźniki cząstkowe uwzględniane w miernikach złożonych powinny posiadać rozkład normalny (Regional Innovation Scoreboard 2014: 6, 8-9). Założenie to spełniła większość ze wskaźników zaprezentowanych w Tabeli 1 . Zmienne, których wartości charakteryzowały się wysokim stopniem skośności ${ }^{2} \mathrm{w}$ próbie (we wszystkich lub w większości analizowanych lat) poddano przekształceniu pierwiastkowemu ${ }^{3}$.

Wskaźnik syntetyczny zbudowano jako średnią arytmetyczną znormalizowanych wartości mierników cząstkowych, przy czym do normalizacji zastoso-

${ }^{2}$ Wartość współczynnika skośności powyżej 1.

${ }^{3}$ Przekształcenie to zastosowano dla następujących wskaźników cząstkowych: udział ludności w wieku 30-34 lata $\mathrm{z}$ wyższym wykształceniem; udział nakładów na $\mathrm{B}+\mathrm{R}$ w PKB; udział przychodów netto ze sprzedaży produktów innowacyjnych w przedsiębiorstwach przemysłowych. 
wano metodę unitaryzacji, w której początkowo wyznacza się różnicę pomiędzy wartościami wskaźnika dla poszczególnych województw a wartością minimalną wskaźnika obserwowaną we wszystkich województwach, a następnie wynik dzieli się przez różnicę między maksymalną i minimalną wartością wskaźnika obserwowaną we wszystkich województwach. W celu możliwości dokonywania porównań wartości wskaźnika syntetycznego w czasie, w procedurze tej uwzględniono wartości maksymalne i minimalne wskaźników cząstkowych pochodzące z całego analizowanego okresu. Wartości wskaźnika syntetycznego unormowane są $\mathrm{w}$ przedziale $(0,1)$. Szczegółowe wyniki zaprezentowano w Tabeli 2.

Tabela 2. Wartości syntetycznego wskaźnika innowacyjności i pozycja województw w rankingu w latach 2008-2013

\begin{tabular}{|l|r|r|r|r|r|r|r|r|r|r|r|r|r|}
\hline \multirow{2}{*}{ Województwo } & \multicolumn{2}{|c|}{2008} & \multicolumn{2}{|c|}{2009} & \multicolumn{2}{|c|}{2010} & \multicolumn{2}{c|}{2011} & \multicolumn{2}{|c|}{2012} & \multicolumn{2}{|c|}{2013} \\
\cline { 2 - 15 } & W* & P* & \multicolumn{1}{|c|}{ W } & P & W & P & W & P & W & P & W & P \\
\hline Dolnośląskie & 0,61 & 2 & 0,49 & 3 & 0,51 & 3 & 0,43 & 5 & 0,56 & 2 & 0,52 & 3 \\
\hline Kujawsko-Pomorskie & 0,34 & 12 & 0,32 & 10 & 0,32 & 13 & 0,28 & 12 & 0,32 & 13 & 0,28 & 15 \\
\hline Lubelskie & 0,42 & 7 & 0,39 & 6 & 0,35 & 8 & 0,36 & 8 & 0,40 & 6 & 0,37 & 9 \\
\hline Lubuskie & 0,34 & 11 & 0,23 & 16 & 0,29 & 16 & 0,22 & 16 & 0,30 & 15 & 0,33 & 12 \\
\hline Łódzkie & 0,32 & 13 & 0,31 & 12 & 0,32 & 12 & 0,32 & 10 & 0,39 & 7 & 0,39 & 8 \\
\hline Małopolskie & 0,53 & 5 & 0,46 & 4 & 0,47 & 5 & 0,49 & 2 & 0,54 & 3 & 0,53 & 2 \\
\hline Mazowieckie & 0,74 & 1 & 0,61 & 1 & 0,62 & 1 & 0,55 & 1 & 0,64 & 1 & 0,64 & 1 \\
\hline Opolskie & 0,39 & 10 & 0,34 & 9 & 0,35 & 9 & 0,34 & 9 & 0,35 & 11 & 0,36 & 10 \\
\hline Podkarpackie & 0,44 & 6 & 0,37 & 7 & 0,43 & 6 & 0,41 & 7 & 0,39 & 8 & 0,42 & 6 \\
\hline Podlaskie & 0,40 & 8 & 0,31 & 13 & 0,31 & 15 & 0,28 & 11 & 0,37 & 10 & 0,39 & 7 \\
\hline Pomorskie & 0,58 & 3 & 0,44 & 5 & 0,51 & 2 & 0,49 & 3 & 0,46 & 4 & 0,44 & 4 \\
\hline Śląskie & 0,54 & 4 & 0,51 & 2 & 0,50 & 4 & 0,45 & 4 & 0,46 & 5 & 0,43 & 5 \\
\hline Świętokrzyskie & 0,31 & 14 & 0,25 & 15 & 0,32 & 14 & 0,23 & 15 & 0,30 & 14 & 0,30 & 14 \\
\hline Warmińsko-Mazurskie & 0,24 & 16 & 0,31 & 11 & 0,33 & 11 & 0,25 & 14 & 0,22 & 16 & 0,24 & 16 \\
\hline Wielkopolskie & 0,39 & 9 & 0,36 & 8 & 0,42 & 7 & 0,43 & 6 & 0,37 & 9 & 0,36 & 11 \\
\hline Zachodniopomorskie & 0,30 & 15 & 0,31 & 14 & 0,34 & 10 & 0,27 & 13 & 0,32 & 12 & 0,32 & 13 \\
\hline
\end{tabular}

* W - wartość wskaźnika; P - pozycja województwa w rankingu.

Źródło: opracowanie własne.

W następnym kroku dokonano grupowania województw ze względu na poziom innowacyjności w każdym roku analizy (wyniki dla roku 2008 i roku 2013 na Rysunku 1). Wyróżniono 4 grupy (Regional Innovation... 2014: 41): liderów 
innowacyjności charakteryzujących się poziomem innowacyjności co najmniej o 25\% wyższym od średniej dla Polski, innowatorów „doganiających” (ang. followers) z wartością wskaźnika do $25 \%$ powyżej średniej, innowatorów „umiarkowanych” (ang. moderate) z wartością wskaźnika najwyżej o 25\% niższą od średniej oraz innowatorów „skromnych” (ang. modest), dla których wskaźnik innowacyjności osiągnął poziom o $25 \%$ niższy niż średnia wartość dla Polski.
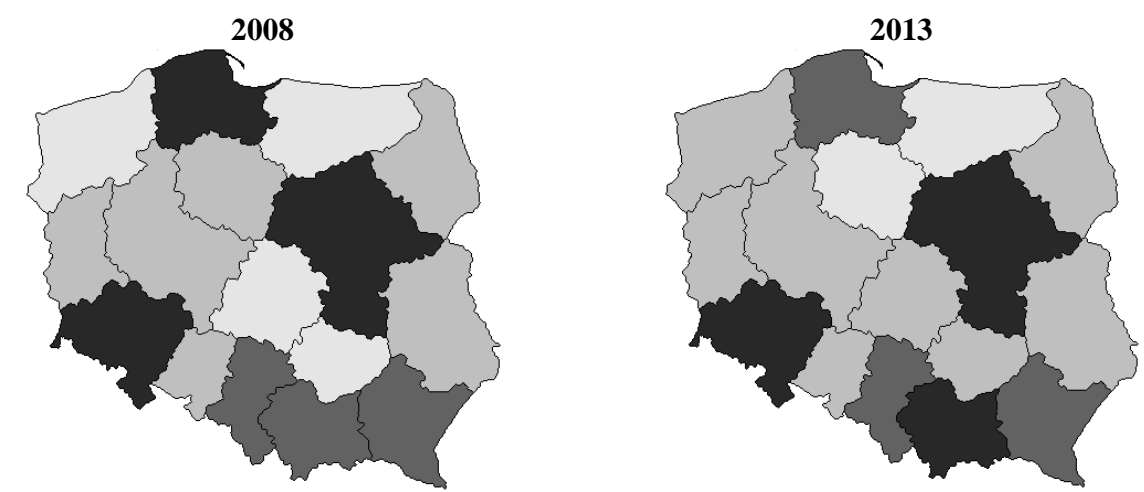

— Liderzy innowacyjności

- Innowatorzy doganiający

Umiarkowani innowatorzy

Skromni innowatorzy

Rysunek 1. Grupowanie województw ze względu na poziom innowacyjności w 2008 i 2013 roku

Źródło: opracowanie własne.

Liczba województw zakwalifikowanych do grupy liderów nie uległa zmianie w analizowanym okresie. W roku 2013 grupę tę tworzyły województwa: mazowieckie, dolnośląskie oraz małopolskie, które zajęło miejsce województwa pomorskiego. W roku 2013, w porównaniu z rokiem 2008, swoją pozycję poprawiły również województwa: łódzkie, świętokrzyskie i zachodniopomorskie należące do grupy innowatorów umiarkowanych, natomiast województwo kujawsko-pomorskie dołączyło do warmińsko-mazurskiego reprezentującego w 2013 roku najniższy poziom innowacyjności.

Na Wykresie 1 zaprezentowano przebieg zmian wartości wskaźnika innowacyjności w województwach zakwalifikowanych do poszczególnych grup w latach 2008-2013. 

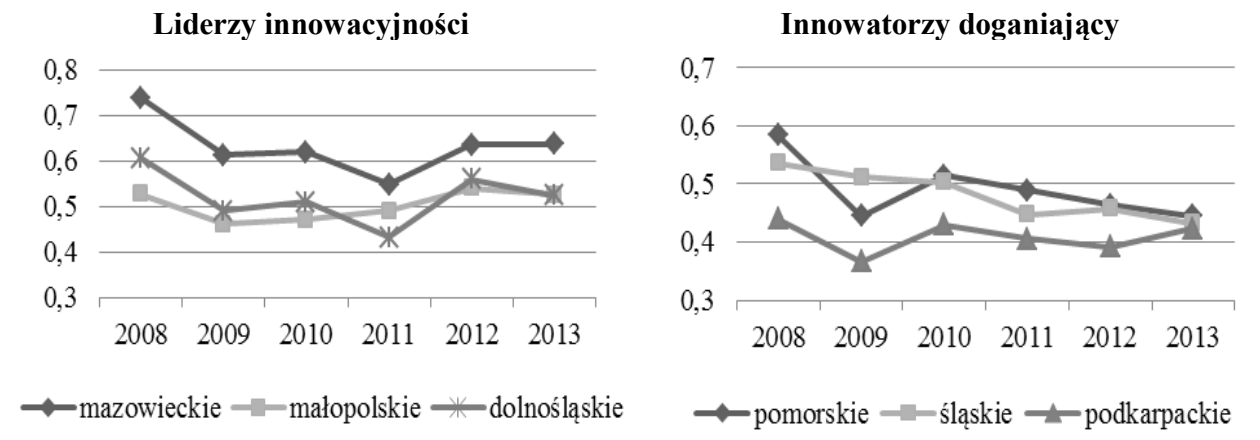

Umiarkowani innowatorzy
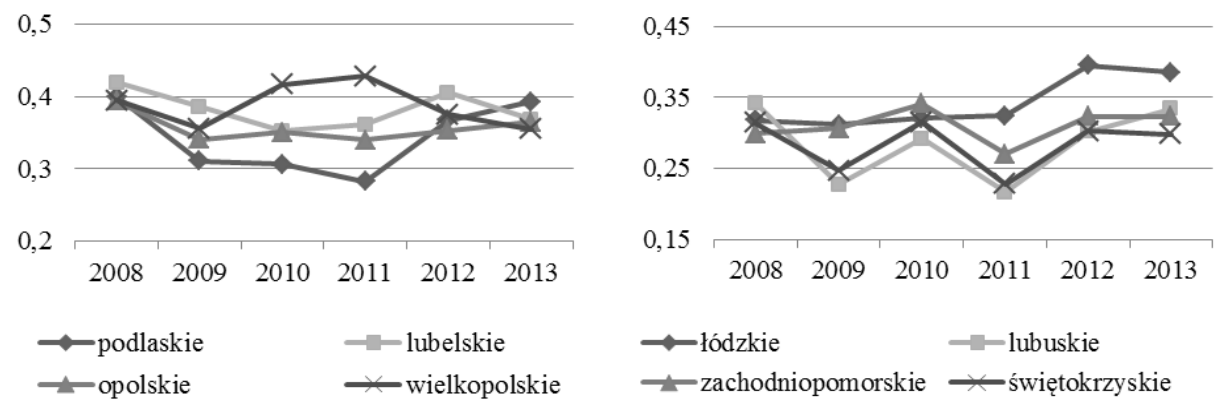

Skromni innowatorzy

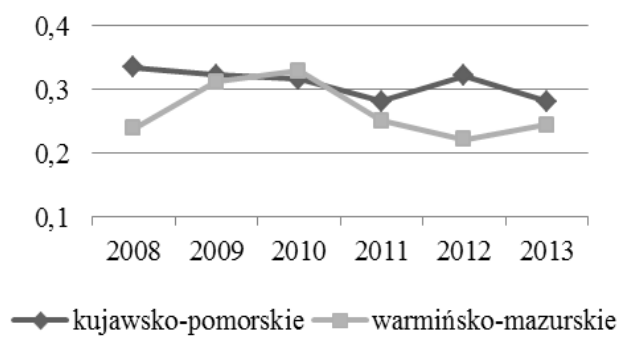

Wykres 1 . Zmiany wartości wskaźnika innowacyjności w grupach województw ${ }^{4}$ w latach 2008-2013

Źródło: opracowanie własne.

Analiza zmian wartości wskaźnika w grupie liderów innowacyjności wskazuje na duże podobieństwo przebiegu zmian w województwach, szczególnie w województwie mazowieckim i dolnośląskim, gdzie do roku 2011 obserwowano spadek tej wartości, a następnie ponowny wzrost w roku 2013. W grupie innowatorów „doganiających” praktycznie w całym analizowanym okresie

\footnotetext{
${ }^{4}$ Grupy województw wyodrębnione na podstawie wartości wskaźnika w 2013 roku.
} 
widoczny był spadek wartości wskaźnika innowacyjności (z wyjątkiem roku 2010 w województwie pomorskim i podkarpackim, gdzie odnotowano wzrost w stosunku do roku 2009). W grupie innowatorów „umiarkowanych” (w województwach o wyższych wartościach wskaźnika) we wszystkich województwach poza wielkopolskim obserwowano spadek wartości wskaźnika trwający do 2011 roku, a następnie wzrost (największy w przypadku województwa podlaskiego). W województwie wielkopolskim zaobserwowano odwrotny przebieg zmian w analizowanym okresie. W drugiej podgrupie innowatorów „umiarkowanych” wartość wskaźnika podlegała w latach 2008-2013 wahaniom, by ostatecznie osiągnąc poziom zbliżony do obserwowanego w roku 2008. Wyjątek stanowi województwo łódzkie, dla którego wartość wskaźnika uległa zwiększeniu. Wśród województw sklasyfikowanych w grupie „skromnych" innowatorów obserwowano odmienne tendencje zmian wartości wskaźnika, przy czym w roku 2013 województwa te charakteryzowały się zbliżonym poziomem innowacyjności.

\section{ZMIANY STRUKTURY PRACUJĄCYCH NA REGIONALNYCH RYNKACH PRACY W POLSCE}

\subsection{Struktura sektorowa pracujących}

W latach 2008-2013 w większości województw w Polsce obserwowano zmiany trójsektorowej struktury zatrudnienia wyrażające się spadkiem udziału pracujących $\mathrm{w}$ rolnictwie oraz $\mathrm{w}$ przemyśle, przy jednoczesnym wzroście udziału zatrudnionych w usługach (Wykres 2). Wyjątek stanowi województwo podlaskie będące regionem typowo rolniczym, w którym zaobserwowano odwrotny kierunek zmian w zatrudnieniu - wzrost udziału pracujących w rolnictwie kosztem zmniejszenia udziału sektora usługowego i, w niewielkim stopniu, sektora przemysłowego. Stopniowe zmniejszanie dominacji sektora rolniczego w zatrudnieniu obserwowane jest natomiast w województwie lubelskim, podkarpackim, świętokrzyskim czy kujawsko-pomorskim. Z kolei w województwie zachodniopomorskim posiadającym jeden $z$ najwyższych udziałów zatrudnienia w usługach oraz w opolskim ze stosunkowo wysokim udziałem pracujących w przemyśle odnotowano w analizowanym okresie nieznaczny wzrost udziału sektora rolniczego w zatrudnieniu. 


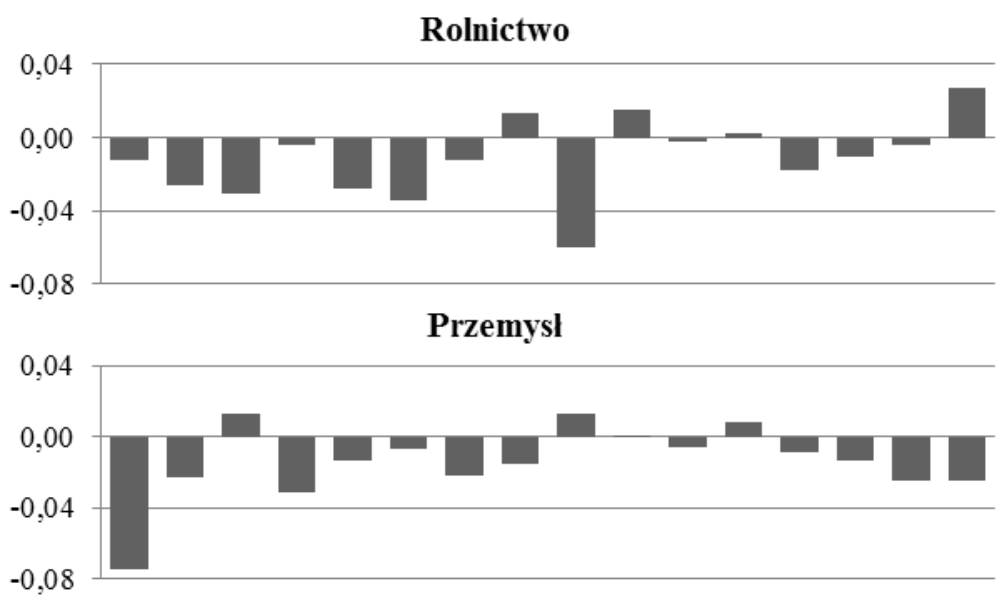

\section{Uslugi}

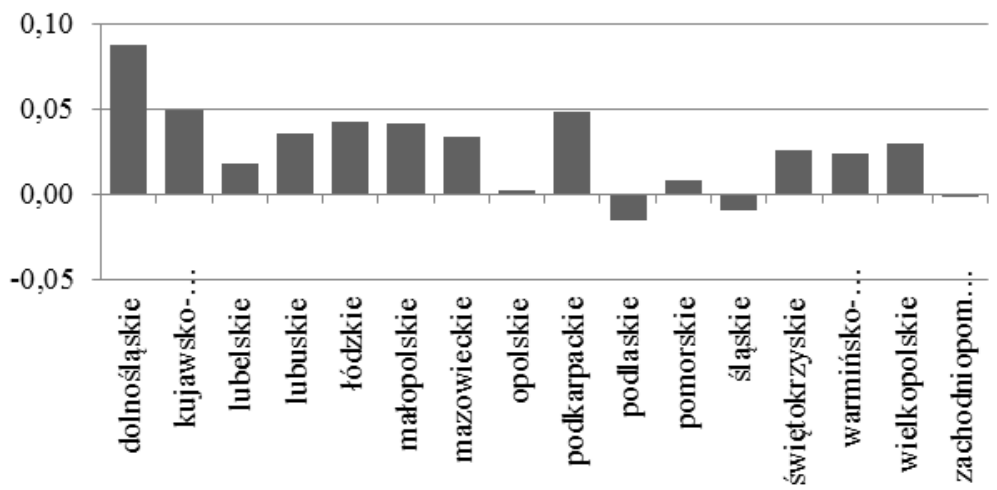

Wykres 2. Zmiany struktury (w p. proc.) pracujących w przekroju trzech sektorów gospodarki w województwach w latach 2008-2013

Źródło: opracowanie własne.

Prawidłowość, jaką zaobserwowano w zmianach struktury pracujących w Polsce, zgodnie z koncepcją trójsektorowej struktury gospodarczej, stanowi jeden z przejawów zwiększania poziomu rozwoju, w tym także wzrostu innowacyjności gospodarek (Drążkiewicz, Kusideł, Penszko 2011: 24). Sektor usług wykorzystujący w coraz większej mierze nowe technologie, bazujący na specjalistycznych umiejętnościach i wiedzy zawodowej uznawany jest bowiem za kluczowy w procesie rozwoju gospodarki opartej na wiedzy. W szczególności podkreśla się rolę tych działalności usługowych, które przyczyniają się do tworzenia i rozpowszechniania wiedzy i informacji (Węgrzyn 2013: 55-57).

W oparciu o klasyfikację PKD 2007 (Dz.U. 2007 poz. 1885) wyróżniono siedem sekcji klasyfikowanych w ramach sektora usługowego, które obejmują w większości działalności zaliczane do tzw. usług opartych na zaawansowanej 
wiedzy (GUS 2014: 20-23). Do sekcji tych należą: Informacja i komunikacja (J), Działalność finansowa i ubezpieczeniowa $(\mathrm{K})$, Działalność profesjonalna, naukowa i techniczna $(\mathrm{M})$, Administracja publiczna i obrona narodowa $(\mathrm{O})$, Edukacja (P), Opieka zdrowotna i pomoc społeczna (Q) oraz Działalność związana z kulturą, rozrywka i rekreacją (R). W roku 2013 stosunkowo wysokie udziały w zatrudnieniu w Polsce spośród wszystkich sekcji z sektora usług miały: sekcja $\mathrm{P}(7,8 \%), \mathrm{O}(6,9 \%)$, a także M $(3,3 \%)$, przy czym analiza zmian udziałów pracujących w latach 2008-2013 we wszystkich wymienionych sekcjach wskazuje na wzrost ich znaczenia w zatrudnieniu zarówno na poziomie krajowym, jak i wojewódzkim. Największe wzrosty odnotowano w sekcjach Q (o 0,7 p. proc. w Polsce; wzrost odnotowany w 13 województwach), M (0,6 p. proc. w Polsce; wzrost w 12 województwach) oraz $\mathrm{O}$ (blisko 0,6 p. proc. w Polsce; wzrost w 13 województwach).

Analizę pogłębiono badaniem zmian udziałów pracujących w podziale na sektory wyróżnione ze względu na poziom zaawansowania techniki i zaangażowania wiedzy stosowanym przez Eurostat w ujęciu sektorowym statystyki nauki, techniki i innowacji. Kryterium klasyfikacji poszczególnych dziedzin przemysłu do czterech sektorów: wysokiej techniki, średnio-wysokiej techniki, średnioniskiej techniki i niskiej techniki, oraz dziedzin z sektora usług do sektora usług opartych na zaawansowanej wiedzy (KIS) i usług mniej wiedzochłonnych (LKIS, ang. Less Knowledge Intensive Services) stanowi odpowiednio: w sektorze przemysłowym - poziom zawartości komponentu $\mathrm{B}+\mathrm{R}$ stanowiącego udział nakładów na $\mathrm{B}+\mathrm{R}$ (badania $\mathrm{i}$ rozwój) w wartości dodanej, a w sektorze usługowym - udział osób z wyższym wykształceniem (Baza metadanych Eurostat).

Analiza zmian udziałów pracujących w sektorach wyróżnionych ze względu na poziom techniki w przemyśle i zaangażowania wiedzy w usługach w latach 2008-2013 (Wykres 3) wskazuje, że we wszystkich województwach nastąpił wzrost udziału pracujących w sektorze usług opartych na zaawansowanej wiedzy oraz spadek udziału pracujących w przemyśle niskiej techniki (poza województwem podkarpackim - udział bez zmian), przy czym w 2013 roku sektor ten nadal charakteryzował się największym udziałem w zatrudnieniu (średnio $8,5 \%$ w Polsce). Nieznacznie wzrósł udział pracujących w przemyśle średnioniskiej techniki, a udział sektora wysokiej i średnio-wysokiej techniki w zatrudnieniu był nadal bardzo niski (około 5\% w skali kraju).

Jednocześnie wzrost udziału pracujących $\mathrm{w}$ sektorze wysokiej i średniowysokiej techniki w przemyśle odnotowano w województwie małopolskim oraz opolskim, a w województwach łódzkim, podlaskim oraz lubuskim, śląskim i podkarpackim dodatkowo również $\mathrm{w}$ przemyśle średnio-niskiej techniki. $\mathrm{W}$ trzech ostatnich z wymienionych województw nastąpił jednocześnie wyraźny wzrost udziału zatrudnienia w usługach opartych na wiedzy. W województwie kujawsko-pomorskim, świętokrzyskim oraz zachodniopomorskim i warmińsko- 
mazurskim odnotowano wzrost udziału zatrudnienia w przemyśle średnio-niskiej techniki, przy czym w dwóch ostatnich $\mathrm{z}$ wymienionych dodatkowo nastąpił spadek udziału pracujących w usługach mniej wiedzochłonnych na rzecz usług opartych na wiedzy. W województwie dolnośląskim, lubelskim, mazowieckim oraz pomorskim i wielkopolskim odnotowano spadek udziału pracujących we wszystkich kategoriach działalności przemysłowej i jednoczesny wzrost udziału pracujących w usługach, głównie opartych na zaawansowanej wiedzy.

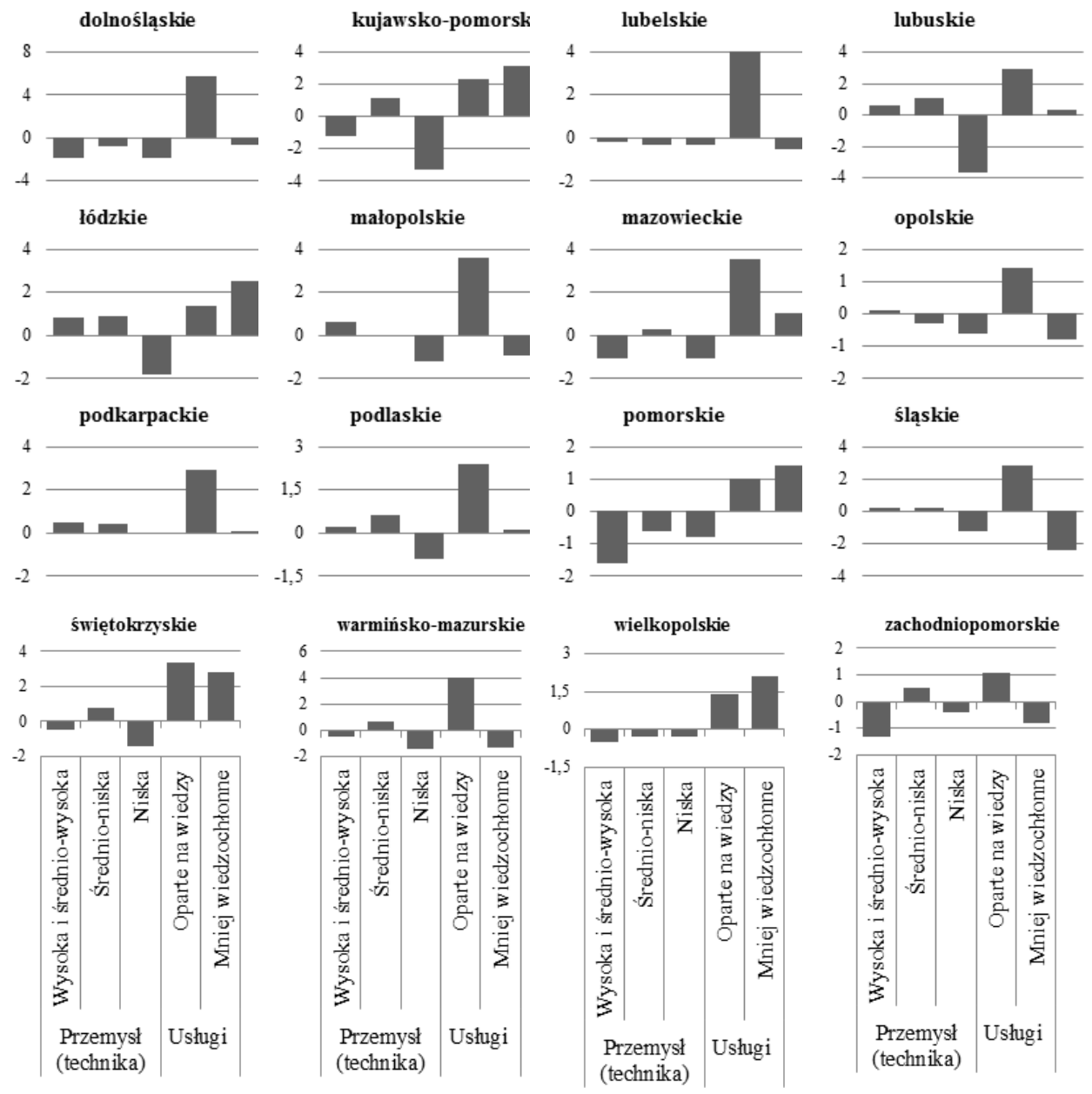

Wykres 3. Zmiany struktury (w p. proc.) pracujących w przekroju sektorów wyróżnionych ze względu poziom techniki i wiedzy w województwach w latach 2008-2013

Źródło: opracowanie własne. 


\subsection{Struktura zawodowo-kwalifikacyjna pracujących}

Analizę struktury zawodowo-kwalifikacyjnej w województwach w Polsce przeprowadzono w oparciu o dane dotyczące liczby pracujących w 9 wielkich grupach zawodowych ${ }^{5}$, zgodnie z klasyfikacją zawodów i specjalności (Dz.U. 2014 poz. 1145). Podstawę grupowania poszczególnych zawodów do wielkich grup zawodowych stanowi podobieństwo kwalifikacji wymaganych dla realizacji zadań danego zawodu. W klasyfikacji uwzględniono cztery szerokie poziomy kompetencji określone w Międzynarodowym Standardzie Klasyfikacji Zawodów (ISCO-08) (ILO 2012: 12-15) oraz odpowiadające im poziomy kształcenia ${ }^{6}$ określone w Międzynarodowej Standardowej Klasyfikacji Edukacji (ISCED 2011) (UNESCO-UIS 2012: 25-61), które następnie przyporządkowano poszczególnym grupom wielkim.

W latach 2008-2013 w większości województw (poza lubuskim i zachodniopomorskim) zaobserwowano wzrost udziału pracujących $\mathrm{w}$ grupie zawodowej specjalistów reprezentujących wysokie kwalifikacje zawodowe związanych z posiadaniem wykształcenia wyższego, przy czym najwyższe wzrosty odnotowano w województwach: dolnośląskim, mazowieckim, pomorskim oraz małopolskim (Wykres 4). Jednocześnie województwa te charakteryzowały się najwyższym udziałem pracujących w tej grupie zawodowej w 2013 roku. Druga grupa zawodowa charakteryzująca się równie wysokim poziomem kwalifikacji przedstawiciele władz publicznych, wyżsi urzędnicy i kierownicy - nie wykazywała w analizowanym okresie dużych zmian, przy czym w większości województw nastąpił nieznaczny spadek jej udziału w zatrudnieniu. Podobna sytuacja miała miejsce wśród techników i innego średniego personelu reprezentujących średni poziom kwalifikacji, jednak w tej grupie spadki udziału w zatrudnieniu obserwowane $\mathrm{w}$ większości województw były silniejsze.

Zdecydowanie zwiększył się udział pracowników usług osobistych i sprzedawców w zatrudnieniu (5. wielka grupa zawodowa) - wzrost udziału tej grupy odnotowano w 15 województwach (poza mazowieckim, gdzie nastąpił nieznaczny spadek). Wyraźne spadki w większości województw zaobserwowano natomiast wśród rolników, leśników, ogrodników i rybaków (największe w województwie podkarpackim i małopolskim) oraz wśród robotników przemysłowych i rzemieślników (najsilniejsze w dolnośląskim i śląskim), którzy reprezentują stosunkowo niski poziom kwalifikacji. Spadki udziału pracujących w większości województw odnotowano również w kolejnej grupie pracowników o niskich kwalifikacjach zawodowych - wśród operatorów i monterów maszyn i urządzeń (największe w województwie dolnośląskim i lubuskim). Udział grupy

\footnotetext{
${ }^{5}$ Grupę zawodową 0: Siły zbrojne pominięto w analizie ze względu na jej niską liczebność.

${ }^{6}$ Zgodnie z klasyfikacją ISCED 2011 wyższym poziomom wykształcenia odpowiadają wyższe kwalifikacje, większy zasób posiadanej wiedzy, stopień zaawansowania umiejętności i kompetencji zdobywanych w systemie kształcenia.
} 
charakteryzującej się najniższym poziomem kwalifikacji w zatrudnieniu - pracowników przy pracach prostych - zmniejszył się w analizowanym okresie we wszystkich województwach poza łódzkim i lubuskim, gdzie odnotowano nieznaczny wzrost tego udziału.
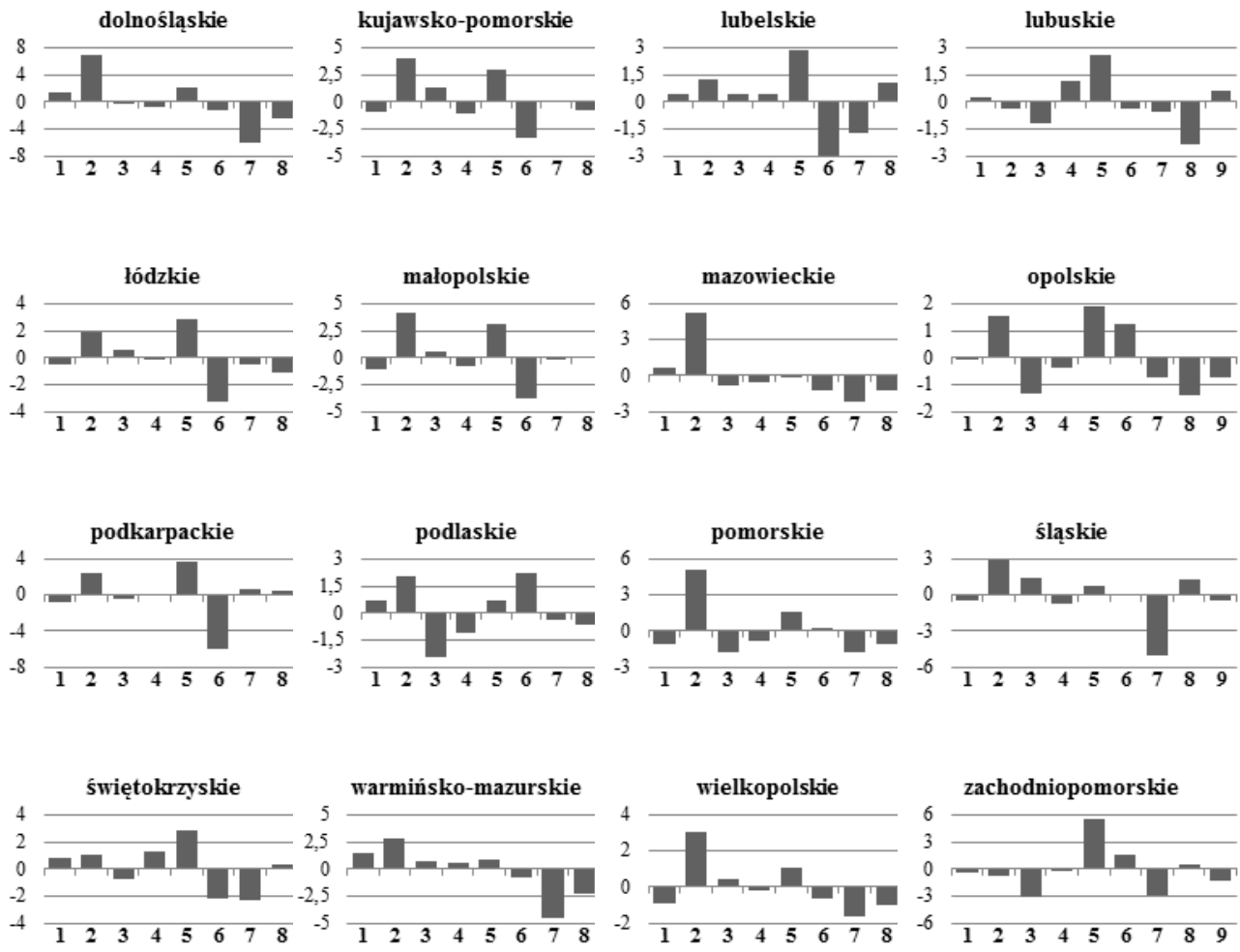

* Wielkie grupy zawodowe: 1: Przedstawiciele władz publicznych, wyżsi urzędnicy i kierownicy; 2: Specjaliści; 3: Technicy i inny średni personel; 4: Pracownicy biurowi, 5: Pracownicy usług osobistych i sprzedawcy; 6: Rolnicy, ogrodnicy, leśnicy i rybacy; 7: Robotnicy przemysłowi i rzemieślnicy; 8: Operatorzy i monterzy maszyn i urządzeń; 9: Pracownicy przy pracach prostych.

Wykres 4. Zmiany struktury (w p. proc.) pracujących w przekroju grup zawodowych w województwach w latach 2008-2013

Źródło: opracowanie własne.

\section{POZIOM INNOWACYJNOŚCI A ZMIANY STRUKTURY ZATRUDNIENIA - PRÓBA IDENTYFIKACJI ZALEŻNOŚCI}

W celu zbadania zależności pomiędzy poziomem innowacyjności a zmianami, jakie zaszły w wojewódzkich strukturach zatrudnienia, w pierwszej kolejności przeprowadzono analizę korelacji pomiędzy syntetycznym wskaźnikiem 
innowacyjności a udziałami pracujących $\mathrm{w}$ poszczególnych grupach zawodowych, sektorach i sekcjach. Jednocześnie w analizie korelacji wykorzystano zmodyfikowany wskaźnik innowacyjności, z którego usunięto dwie zmienne odnoszące się bezpośrednio do struktury zatrudnienia w województwach ${ }^{7}$. W Tabeli 3 zamieszczono współczynniki korelacji z poszczególnych lat analizy. Kolorem szarym zacieniowano te wskaźniki struktury zatrudnienia, dla których uzyskano współczynniki istotne statystycznie bądź bliskie istotności ${ }^{8} \mathrm{~W}$ większości analizowanych lat.

Tabela 3. Współczynniki korelacji między wskaźnikiem innowacyjności i udziałami pracujących w grupach zawodowych, sektorach i sekcjach w latach 2008-2013

\begin{tabular}{|l|r|r|r|r|r|r|}
\hline \multirow{2}{*}{ Wyszczególnienie } & 2013 & 2012 & 2011 & 2010 & 2009 & 2008 \\
\cline { 2 - 7 } & \multicolumn{7}{|c|}{ WI } \\
\hline \multicolumn{1}{|c|}{ Grupy zawodowe } \\
\hline \multicolumn{1}{|c|}{2} & 3 & 4 & 5 & 6 & 7 \\
\hline $\begin{array}{l}\text { Przedstawiciele władz publicznych, wyżsi } \\
\text { urzędnicy i kierownicy (1) }\end{array}$ & 0,57 & 0,33 & 0,27 & 0,43 & 0,18 & 0,45 \\
\hline Specjaliści (2) & 0,79 & 0,84 & 0,74 & 0,81 & 0,59 & 0,35 \\
\hline Technicy i inny średni personel (3) & 0,03 & 0,09 & 0,33 & 0,40 & 0,23 & 0,17 \\
\hline Pracownicy biurowi (4) & 0,53 & 0,23 & 0,12 & 0,29 & 0,72 & 0,77 \\
\hline Pracownicy usług osobistych i sprzedawcy (5) & $-0,33$ & $-0,33$ & $-0,13$ & $-0,33$ & $-0,12$ & 0,07 \\
\hline Rolnicy, leśnicy, ogrodnicy i rybacy (6) & $-0,01$ & $-0,03$ & $-0,01$ & $-0,12$ & $-0,07$ & $-0,05$ \\
\hline Robotnicy przemysłowi i rzemieślnicy (7) & $-0,47$ & $-0,54$ & $-0,46$ & $-0,34$ & $-0,30$ & $-0,32$ \\
\hline Operatorzy i monterzy maszyn i urządzeń (8) & $-0,20$ & $-0,08$ & $-0,20$ & $-0,24$ & $-0,20$ & $-0,04$ \\
\hline Pracownicy przy pracach prostych (9) & $-0,60$ & $-0,70$ & $-0,68$ & $-0,58$ & $-0,45$ & $-0,52$ \\
\hline \multicolumn{7}{|c|}{ Sektory } \\
\hline Rolnictwo & $-0,11$ & $-0,12$ & $-0,08$ & $-0,20$ & $-0,15$ & $-0,12$ \\
\hline Przemysł & $-0,29$ & $-0,25$ & $-0,21$ & $-0,18$ & $-0,13$ & $-0,13$ \\
\hline Usługi rynkowe & 0,58 & 0,52 & 0,46 & 0,54 & 0,52 & 0,42 \\
\hline Usługi nierynkowe & 0,14 & 0,11 & 0,11 & 0,26 & 0,07 & 0,11 \\
\hline \multicolumn{7}{|c|}{ PKD 2007 } \\
\hline $\begin{array}{l}\text { Rolnictwo, leśnictwo, łowiectwo i rybactwo } \\
\text { (A) }\end{array}$ & $-0,11$ & $-0,12$ & $-0,08$ & $-0,20$ & $-0,15$ & $-0,12$ \\
\hline Przetwórstwo przemysłowe (C) & $-0,42$ & $-0,42$ & $-0,34$ & $-0,38$ & $-0,33$ & $-0,19$ \\
\hline
\end{tabular}

${ }^{7}$ Ze wskaźnika usunięto zmienne: Udział pracujących w przemyśle wysokiej i średniowysokiej techniki w ogólnej liczbie pracujących (w \%); Udział pracujących w usługach „,opartych na wiedzy" w ogólnej liczbie pracujących (w \%).

${ }^{8}$ Poziom krytyczny współczynnika korelacji na poziomie istotności $\alpha=0,05$ dla analizowanej próby (16 obiektów) wynosi $r^{*}=0,497$. 
Tabela 3 (cd.)

\begin{tabular}{|c|c|c|c|c|c|c|}
\hline 1 & 2 & 3 & 4 & 5 & 6 & 7 \\
\hline \multicolumn{7}{|c|}{ Zawierające w większości usługi oparte na zaawansowanej wiedzy (KIS) } \\
\hline Informacja i komunikacja $(\mathrm{J})$ & 0,84 & 0,81 & 0,67 & 0,83 & 0,72 & 0,74 \\
\hline Działalność finansowa i ubezpieczeniowa $(\mathrm{K})$ & 0,69 & 0,69 & 0,59 & 0,62 & 0,45 & 0,61 \\
\hline $\begin{array}{l}\text { Działalność profesjonalna, naukowa } \\
\text { i techniczna }(\mathrm{M})\end{array}$ & 0,71 & 0,69 & 0,66 & 0,74 & 0,60 & 0,57 \\
\hline $\begin{array}{l}\text { Administracja publiczna i obrona narodowa } \\
\text { (O) }\end{array}$ & $-0,43$ & $-0,51$ & $-0,44$ & $-0,32$ & $-0,42$ & $-0,29$ \\
\hline Edukacja $(\mathrm{P})$ & 0,10 & $-0,05$ & 0,24 & 0,16 & $-0,24$ & $-0,32$ \\
\hline Opieka zdrowotna i pomoc społeczna $(\mathrm{Q})$ & $-0,26$ & 0,16 & 0,22 & 0,31 & 0,38 & 0,14 \\
\hline $\begin{array}{l}\text { Działalność związana z kulturą, rozrywka } \\
\text { i rekreacją (R) }\end{array}$ & 0,48 & 0,65 & 0,26 & 0,38 & 0,53 & 0,29 \\
\hline Sekcje KIS lącznie & 0,48 & 0,42 & 0,40 & 0,54 & 0,31 & 0,25 \\
\hline \multicolumn{7}{|c|}{ Zawierające w większości usługi mniej wiedzochłonne (Less KIS) } \\
\hline $\begin{array}{l}\text { Handel hurtowy i detaliczny; naprawa pojaz- } \\
\text { dów samochodowych }(\mathrm{G})\end{array}$ & 0,26 & 0,25 & 0,50 & 0,30 & 0,23 & 0,04 \\
\hline Transport i gospodarka magazynowa $(\mathrm{H})$ & 0,01 & 0,02 & $-0,13$ & $-0,09$ & $-0,19$ & $-0,04$ \\
\hline $\begin{array}{l}\text { Działalność związana z zakwaterowaniem } \\
\text { i usługami gastronomicznymi (I) }\end{array}$ & 0,15 & 0,34 & 0,22 & 0,17 & 0,21 & 0,29 \\
\hline $\begin{array}{l}\text { Działalność związana z obsługą rynku nieru- } \\
\text { chomości (L) }\end{array}$ & 0,08 & 0,07 & 0,15 & 0,31 & 0,23 & 0,45 \\
\hline Działalność w zakresie usług administr. $(\mathrm{N})$ & 0,25 & 0,24 & $-0,13$ & 0,12 & 0,24 & 0,48 \\
\hline Pozostała działalność usługowa (S) & $-0,06$ & $-0,13$ & $-0,06$ & $-0,03$ & $-0,15$ & 0,23 \\
\hline $\begin{array}{l}\text { Gospodarstwa domowe zatrudniające pra- } \\
\text { cowników (T) }\end{array}$ & 0,24 & 0,19 & 0,15 & $-0,04$ & 0,09 & 0,42 \\
\hline Sekcje LKIS lącznie & 0,23 & 0,22 & 0,11 & 0,17 & 0,21 & 0,31 \\
\hline \multicolumn{7}{|c|}{ Sektory wyróżnione ze względu na poziom zaawansowania techniki i zaangażowania wiedzy } \\
\hline \multicolumn{7}{|c|}{ Przemysi } \\
\hline Wysoka i średnio-wysoka technika łącznie & 0,11 & 0,18 & 0,14 & 0,21 & 0,16 & 0,29 \\
\hline Średnio-wysoka technika & 0,10 & 0,23 & 0,29 & 0,24 & 0,26 & 0,21 \\
\hline Niska i średnio-niska technika łącznie & $-0,24$ & $-0,36$ & $-0,06$ & $-0,31$ & $-0,18$ & $-0,36$ \\
\hline Średnio-niska technika & $-0,24$ & $-0,23$ & $-0,14$ & $-0,11$ & $-0,15$ & 0,03 \\
\hline Niska technika & $-0,49$ & $-0,56$ & $-0,43$ & $-0,55$ & $-0,54$ & $-0,59$ \\
\hline \multicolumn{7}{|c|}{ Usługi } \\
\hline Oparte na wiedzy & 0,47 & 0,47 & 0,28 & 0,44 & 0,37 & 0,37 \\
\hline Mniej wiedzochłonne & 0,11 & 0,12 & 0,17 & 0,26 & 0,08 & 0,21 \\
\hline
\end{tabular}

Źródło: opracowanie własne.

W analizie przyjęto, że zależność pomiędzy badanymi charakterystykami jest obserwowana, jeżeli współczynniki korelacji dla nich obliczone są istotne statystycznie dla więcej niż połowy analizowanych okresów. Zgodnie z powyż- 
szym należy wskazać na stosunkowo silną dodatnią zależność pomiędzy poziomem innowacyjności a udziałem pracujących w 2. wielkiej grupie zawodowejSpecjaliści, jak również na związek o umiarkowanej sile z udziałem pracujących w sektorze usług rynkowych. W przekroju sekcji PKD 2007 szczególną uwagę zwracają wysokie wartości współczynników korelacji dla udziału pracujących w sekcji J - Informacja i komunikacja oraz stosunkowo wysokie wartości w sekcjach M - Działalność profesjonalna, naukowa i techniczna, oraz K - Działalność finansowa i ubezpieczeniowa w całym analizowanym okresie. Charakter tej zależności jest zgodny z oczekiwaniami, jako że zmiany poziomu innowacyjności i udziału pracujących w powyższych sekcjach, które można zakwalifikować do usług opartych na zaawansowanej wiedzy, przebiegają w tym samym kierunku. Jednocześnie, zaobserwowano stosunkowo wyraźny ujemny związek pomiędzy poziomem innowacyjności a udziałem pracujących w 9. grupie zawodowej (pracownicy przy pracach prostych) oraz udziałem pracujących w przemyśle niskiej techniki. Ujemne wartości współczynników korelacji odnotowano również dla sekcji $\mathrm{O}$ - Administracja publiczna i obrona narodowa, przy czym współczynniki te przyjęły wartości poniżej poziomu krytycznego. Niemniej jednak sekcja O, pomimo zaklasyfikowania jej do sektora usług opartych na wiedzy, wykazywała ujemny związek z poziomem innowacyjności.

Kolejnym etapem badania była próba określenia kierunku związku przyczynowego pomiędzy poziomem innowacyjności a strukturą rynku pracy. W tym celu, kierując się charakterem dostępnych danych statystycznych ${ }^{9}$, zdecydowano się na oszacowanie jednorównaniowych modeli przyczynowo-skutkowych dla danych panelowych za pomocą klasycznej metody najmniejszych kwadratów (KMNK), w których zmienną objaśnianą były udziały pracujących w poszczególnych grupach zawodowych, sektorach i sekcjach, a zmienną objaśniającą każdorazowo syntetyczny wskaźnik innowacyjności. Ze względu na niezadawalające własności oszacowanych modeli, w tym niski stopień dopasowania modeli, brak rozkładu normalnego reszt czy występowanie autokorelacji składnika losowego, uzyskane wyniki nie zostały wykorzystane do wnioskowania na temat przyczynowości pomiędzy badanymi obszarami.

\section{PODSUMOWANIE}

W latach 2008-2013 w Polsce zaobserwowano generalny spadek poziomu innowacyjności mierzonego za pomocą syntetycznego wskaźnika innowacyjności, zbudowanego na potrzeby badania. Spadek ten warunkowany jest w głównej

\footnotetext{
${ }^{9}$ Dane wykorzystane w badaniu, a więc dane przekrojowo-czasowe o niewielkiej liczbie obserwacji w czasie (6 lat), znacznie ograniczają możliwość wykorzystania testu przyczynowości Grangera.
} 
mierze zmniejszeniem wartości kilku składowych uwzględnionych we wskaźniku, a mianowicie: odsetka przedsiębiorstw współpracujących w zakresie działalności innowacyjnej oraz udziału przedsiębiorstw innowacyjnych zarówno w sektorze przemysłowym, jak i usługowym, a także udziału przychodów ze sprzedaży produktów innowacyjnych w przedsiębiorstwach przemysłowych oraz odsetka pracujących w przemyśle wysokiej i średnio-wysokiej techniki. W pozostałych wskaźnikach uwzględnionych w mierniku syntetycznym odnotowano w większości wzrosty ich wartości, szczególnie widoczne we wskaźnikach charakteryzujących jakość zasobów ludzkich i poziom kapitału intelektualnego (odsetek uczestników studiów doktoranckich, odsetek ludności z wyższym wykształceniem, liczba zgłoszonych wynalazków). W przekroju województw najbardziej widoczne spadki wartości wskaźnika innowacyjności odnotowano w województwach zaklasyfikowanych do grupy innowatorów tzw. „doganiających”, czyli charakteryzujących się średniowysokim poziomem innowacyjności na tle pozostałych województw w Polsce, do których w 2013 roku należały województwa: pomorskie, śląskie i podkarpackie. Wśród województw będących liderami innowacyjności obserwowano względną stabilizację poziomu innowacyjności. Wyjątek stanowi województwo mazowieckie charakteryzujące się najwyższą innowacyjnością w Polsce, w którym odnotowano wyraźny spadek tego poziomu. W grupie innowatorów umiarkowanych widoczne były wyraźne wahania poziomu innowacyjności $\mathrm{w}$ analizowanym okresie, przy czym $\mathrm{w}$ roku 2013 większość województw, poza województwem łódzkim, osiągnęło poziom zbliżony do obserwowanego w roku 2008. Poziom innowacyjności w województwach zakwalifikowanych do grupy innowatorów tzw. „skromnych” (kujawsko-pomorskie, warmińsko-mazurskie) nie uległ większym zmianom.

Analiza zmian struktury pracujących wskazała, że w większości województw zaobserwowano spadek udziału pracujących w rolnictwie oraz w przemyśle, przy jednoczesnym wzroście udziału zatrudnionych w usługach, a w szczególności w usługach opartych na zaawansowanej wiedzy (KIS). W sektorze przemysłowym obserwowany jest natomiast głównie spadek udziału pracujących w przemyśle niskiej techniki i wzrost udziału pracujących w sektorze średnio-niskiej techniki.

Zmiany w strukturze zawodowo-kwalifikacyjnej pracujących wyrażają się głównie we wzroście udziału specjalistów w odpowiedzi na rosnący popyt na wysokie kwalifikacje i specjalistyczną wiedzę, a także pracowników usług osobistych i sprzedawców, jako wyraz rosnącego znaczenia usług w strukturze zatrudnienia. Równocześnie obserwowany jest spadek udziału pracujących wśród rolników oraz w pozostałych grupach skupiających zawody niewymagające posiadania wysokich kwalifikacji.

Przeprowadzona analiza korelacji pomiędzy wartością syntetycznego wskaźnika innowacyjności a poszczególnymi wskaźnikami struktury rynku pra- 
cy w przekroju zawodów, sektorów i sekcji PKD 2007 oraz sekcji wyróżnionych ze względu na poziom zaawansowania techniki i wiedzy, wskazała na istnienie dodatniej zależności pomiędzy poziomem innowacyjności a udziałem pracujących specjalistów (2. wielka grupa zawodowa) oraz udziałem pracujących $\mathrm{w}$ sektorze usług rynkowych, a w jego ramach w szczególności w sekcjach obejmujących w większości działalności zaliczane do usług opartych na zaawansowanej wiedzy. Widoczne jest zatem powiązanie poziomu innowacyjności z zasobem pracowników wysoko wykwalifikowanych posiadających specjalistyczną wiedzę i wysoki poziom kompetencji zawodowych. Jednocześnie ujemny związek $\mathrm{z}$ innowacyjnością gospodarek regionalnych zaobserwowano w szczególności dla udziału pracowników przy pracach prostych (9. wielka grupa zawodowa), którzy reprezentują elementarne kwalifikacje zawodowe uzyskiwane na najniższych poziomach kształcenia oraz dla udziału pracujących w przemyśle niskiej techniki, w której intensywność działalności badawczorozwojowej jest najniższa.

Analizy przeprowadzone w ramach badania nie pozwoliły na określenie kierunku związku przyczynowego pomiędzy poziomem innowacyjności a strukturą rynku pracy w analizowanych przekrojach. Oszacowane modele ekonometryczne charakteryzowały się niezadawalającymi własnościami, co uniemożliwiło ich wykorzystanie $w$ dalszych etapach badania. $Z$ tego względu wyniki analiz stanowią przyczynek do bardziej pogłębionych badań nad kierunkiem przyczynowości pomiędzy innowacyjnością a zamianami obserwowanymi w strukturze pracujących.

\section{BIBLIOGRAFIA}

Baza metadanych Eurostat, http://ec.europa.eu/eurostat/cache/metadata/DE/htec_esms.htm [Dostęp 28.07.2015].

Drążkiewicz J., Kusideł E., Penszko P. (2011), Wpływ polityki spójności na poziom i jakość zatrudnienia $w$ krajach Grupy Wyszehradzkiej - podsumowanie $i$ wnioski, Warszawa, http://www.kep.uni.lodz.pl/ewakusidel/index/publikacje.html [Dostęp 28.07.2015].

Gajdos A., Trzeźwińska K, Żmurkow E. (2011), Jakość zasobów pracy i innowacyjność regionalna w Polsce, [w:] M. Jewczak, A. Żółtaszek (red.), Ekonometria przestrzenna i regionalne analizy ekonomiczne, Wydawnictwo Uniwersytetu Łódzkiego, Łódź.

Gajdos A., Żmurkow E. (2012), Skilled personnel supply and the prospects for regional innovative development in Poland, "Comaprative Economic Research. Central and Eastern Europe", vol. 15 , $\mathrm{nr} 4 / 2012$, s. 45-58.

GUS (2014), Działalność innowacyjna przedsiębiorstw w latach 2011-2013, Warszawa.

ILO (2012), International Standard Classification of Occupations ISCO-08, Genewa, http://www.ilo.org [Dostęp 28.07.2015].

Kwiatkowska W. (2007), Zmiany strukturalne na rynku pracy w Polsce, Wydawnictwo Uniwersytetu Łódzkiego, Łódź.

Matusiak K. B. red. (2011), Innowacyjność I transfer technologii. Stownik pojęć, Polska Agencja Rozwoju Przedsiębiorczości, Warszawa, http://www.parp.gov.pl/ [Dostęp 28.07.2015]. 
Regional Innovation Scoreboard 2014 (2014), http://ec.europa.eu/enterprise/policies/innovation/ files/ris/ris-2014_en.pdf [Dostęp 28.07.2015].

Rozporządzenie Ministra Pracy i Polityki Społecznej z 7.08.2014 r. w sprawie klasyfikacji zawodów i specjalności na potrzeby rynku pracy oraz zakresu jej stosowania (Dz.U. 2014 poz. 1145).

Rozporządzenie Rady Ministrów z 24.12.2007 r. w sprawie Polskiej Klasyfikacji Działalności (PKD) (Dz.U. 2007 poz. 1885).

UNESCO-UIS (2012), International Standard Classification of Education ISCED 2011, Kanada, http://www.uis.unesco.org [Dostęp 28.07.2015].

Węgrzyn G. (2013), Sektor ustug w gospodarce opartej na wiedzy - studium komparatystyczne, „Oeconomia Copernicana”, nr 1(2013), s. 53-64, http://apcz.pl/czasopisma/index.php/OeC/ article/ view/ OeC.2013.004/1728 [Dostęp 28.07.2015].

Żmurkow-Poteralska E. (2012), Innowacyjność a rozwój regionalny, [w:] M. Burchard-Dziubińska (red.), Lokalne i globalne uwarunkowania rozwoju gospodarczego, Polskie Towarzystwo Ekonomiczne Oddział w Łodzi, Łódź.

\section{Edyta Żmurkow-Poteralska}

\section{INNOVATIVENESS AND CHANGES IN THE LABOUR MARKET IN POLAND}

Abstract. Innovativeness is an important determinant of changes in the modern economy. These changes occur in all its areas, including the labour market, where the workforce adjusts to the needs of innovative economy. The aim of the paper is an attempt to capture the relationship between the innovativeness and changes occurring in the labour market in Poland. The study covers the measurement and analysis of the innovation level based on the synthetic measure. Next, the analysis of changes in the employment structure across economic activities, technology and knowledge-intensive sectors and occupations and qualifications have been done. The last part covers the research on the relationship between the level of innovation and the structure of employment.

Keywords: innovativeness, synthetic index, labour market, employment structure, relationship. 